\title{
PENGEMBANGAN APLIKASI SISTEM PENDUKUNG KEPUTUSAN BERBASIS WEB DALAM PENENTUAN PEMENANG TENDER MENGGUNAKAN METODE BAYES DAN GROUP TECHNOLOGY
}

\section{DEVELOPMENT OF WEB-BASED DECISION SUPPORT SYSTEM IN TENDER WINNERS DETERMINATION USING BAYES AND GROUP TECHNOLOGY METHOD}

\author{
Lita Asyriati Latif ${ }^{1}$, Said Hi Abbas², Mohamad Jamil ${ }^{3}$ \\ Program Studi Teknik Mesin Universitas Khairun ${ }^{1,2}$, Program Studi Teknik Informatika Universitas Khairun ${ }^{3}$ \\ Jl. Pertamina Kampus II Unkhair Gambesi Ternate-Maluku Utara, 97719, Indonesia ${ }^{123}$ \\ litalatif@unkhair.ac.id
}

Naskah Diterima: 21 Agustus 2017; Direvisi : 22 Agustus 2017; Disetujui : 22 Agustus 2017

\begin{abstract}
Abstrak
Tujuan dilaksanakannya tender adalah untuk memberikan kesempatan yang sama kepada pelaku usaha agar dapat ikut menawarkan harga dan kualitas yang bersaing. Sehingga pada akhirnya dalam pelaksanaan proses tender tersebut akan didapatkan harga yang termurah dengan kualitas yang terbaik. Dalam proses pelelangan sampai dengan proses penetapan pemenang lelang sering menimbulkan permasalahan menggunakan cara serta tahapan konvensional, hal ini sangat tidak efektif melihat dari tahapan proses yang di lakukan sangat memakan waktu sehingga waktu terbuang siasia. Dengan adanya kelemahan proses pengadaan barang/jasa tersebut maka dalam penelitain ini akan dilakukan implementasi metode bayes dan group technolgy dalam sistem pendukun keputusan penentuan pemenang tender proyek pemerintah
\end{abstract}

Kata kunci: Tender, Sistem Pendukung Keputusan, Web, Bayes, Group Technology

\section{Abstract}

The purpose of the tender is to provide equal opportunity to business actors in order to participate in offering competitive price and quality. So in the end in the implementation of the tender process will get the cheapest price with the best quality. In the process of auction up to the process of determining the winning bidder often cause problems using conventional way and stages, it is very ineffective to see from the process stages are done very time consuming so time wasted. With the weakness of the procurement process of goods / services in this research will be implemented bayes and group technolgy method in decision support system of determining the winner of government project tender

Keywords: Tender, Decesion Support System, Web, Bayes, Group Technology 


\section{PENDAHULUAN}

Dalam dunia bisnis, ada istilah yang sering kita dengar yakni lelang atau tender pengadaan barang dan jasa. Proses pengadaan barang dan jasa dalam bidang konstruksi merupakan salah satu prosedur dalam mencari perusahaan, ataupun orang-orang yang mampu diberikan suatu tanggung jawab, terhadap pekerjaan perusahaan dalam pembangunan infrastruktur maupun pengadaan barang. Tender merupakan salah usaha yang dilakukan oleh pemerintah atau suatu instansi untuk memperlihatkan adanya transparansi dalam persaingan usaha ketika diadakannya proyek pengadaan barang dan jasa. Pengadaan Barang/Jasa Pemerintah Menurut Peraturan Presiden (Perpres) Nomor 54 Tahun 2010 tentang Pengadaan Barang/Jasa Pemerintah Tender adalah kegiatan pengadaan barang/jasa yang dibiayai dengan APBN/APBD, baik yang dilaksanakan secara swakelola maupun oleh penyedia barang/jasa. Pelelangan barang/jasa yang dilakukan bersifat umum dari pengadaan barang, seperti mobil pada suatu instansi hingga pengadaan jasa seperti jasa konsultan. Dalam setiap proses pengadaan harus selalu ada perencanaan yang matang agar terjadi kecocokan antara jumlah kebutuhan dan anggaran yang ada sehingga terjadi hubungan proses yang bertujuan memperoleh manfaat yang tinggi dan efisiensi. Kegiatan pengadaan barang dan jasa di sebuah institusi khususnya institusi pemerintah dapat dilakukan dengan 3 (tiga) cara yaitu dengan metode penunjukan langsung, pemilihan langsung dan melalui proses tender. Aturan baku dan ketentuan hukum yang mengatur tentang proses kegiatan pengadaan barang dan jasa di instansi pemerintah diatur dalam Keputusan Presiden (Keppres) Nomor 80 Tahun 2003 beserta aturan- aturan perubahan yang selalu diperbaharui setiap tahunnya. Dalam proses pelelangan sampai dengan proses penetapan pemenang lelang sering menimbulkan permasalahan menggunakan cara serta tahapan konvensional, panitia lelang pun akan disibukkan dengan berbagai hal terkait proses lelang sampai dengan penentuan pemenang hal tersebut sudah tentu memakan waktu, untuk itu diperlukan suatu sistem yang bisa mempercepat dan mempermudah kinerja panitia pengadaan lelang proyek pemerintah dengan hasil yang akurat dan juga dapat menyediakan bukti tambahan untuk memberikan pembenaran. Berdasarkan uraian yang dikemukan di atas, maka rumusan masalah penelitian ini adalah bagaimana mengembangkan aplikasi sistem pendukung keputusan berbasis web dalam penentuan pemenang tender menggunakan metode bayes dan group technology. Tujuan dari penelitian ini adalah menggembangkan aplikasi sistem pendukung keputusan berbasis web dalam penentuan pemenang tender menggunakan metode bayes dan group technology. Implementasi dari kriteria bayes yaitu dengan memanfaatkan bobot masing-masing kategori yang diperoleh berdasarkan banyaknya indikator yang digunakan. Dalam hal ini indikator-indikator tersebut dituangkan dalam pertanyaan-pertanyaan sesuai dengan kategori yang telah ditetapkan. Dari bobot masing-masing kategori maka diperoleh probabilitas dan nilai ambang setiap kategori. Sedangkan metode group technology akan di gunakan untuk mengelompokkan kategori pada metode bayes yang bersifat riil di lapangan yaitu; kategori adminstrasi, kategori keuangan, dan kategori teknis.

Terdapat beberapa penelitian terdahulu yang pernah dibuat terkait pengembangan sistem 
pendukung keputusan dalam penentuan pemenang tender, diantaranya:

1. Penelitian yang dilakukan oleh Mirwan (2011) tentang sistem penunjang keputusan pemenang tender proyek menggunakan metode Anlytical Hierarchy Process (AHP) pada Dinas Pekerjaan Umum Kabupaten Aceh Selatan. Hasil yang didapatkan adalah faktorfaktor penilaian dan alternatif saling dibandingkan sehingga memberikan output nilai intensitas prioritas yang menghasilkan suatu sistem yang memberikan penilaian terhadap setiap perusahaan.

2. Penelitian yang dilakukan oleh Nugraha (2012) tentang sistem pendukung keputusan evaluasi pemilihan pemenang pengadaan aset dengan metode Simple Additive Weighting (SAW). Berdasarkan hasil penelitian, didapatkan informasi mengenai peserta lelang dengan skor dari masing-masing kriteria. Nilai preferensi yang terbesar adalah rekomendasi alternatif yang terpilih sebagai alternatif terbaik (pemenang lelang).

3. Penelitian yang dilakukan oleh Surjawan Jahja (2012) tentang sistem lelang tender dan dealing online berbasis web. Aplikasi yang diusulkan dibuat untuk mempermudah kontraktor untuk mengikuti tender secara online

4. Penelitian yang dilakukan oleh (Siska, 2014) tentang sistem pendukung keputusan seleksi penyediaan pengadaan jasa konstruksi dengan metode evaluasi penawaran merit point sistem. Dalam penelitian ini sistem yang diusulkan dikembangkan menggunakan Microsoft Visual Basic.net dengan hasil yang didapat berupa perhitungan nilai evaluasi.
5. Penelitian yang dilakukan oleh Widayantoro, (2013) tentang sistem pendukung keputusan pemenang lelang proyek pemerintah menggunakan metode bayes. Sistem ini diusulkan menggunakan kriteria bayes dalam melakukan penilaian terhadap kriteria-kriteria yang ada dalam proses tender. Aplikasi dikembangkan menggunakan Microsoft Visual Basic 6.0

6. Penelitian yang dilakukan oleh (Jamil M, 2010) tentang pengelompokan potensi pariwisata dan kebudayaan untuk inventarisasi aset pariwisata di Propinsi Maluku Utara menggunakan konsep group technology. Hasil penelitian menemukan bahwa group technology mampu menyelesaikan masalah dengan mengelompokkan komponen ke dalam sistem kodefikasi dari kesamaan karakteristik

7. (Budi, 2014) dalam penelitianya dengan judul DSS menggunakan metode group technology untuk pelayanan Teknis PT. PLN Rayon Ngunut didapatkan pengelompokkan jenis gangguan, gejala gangguan, tools, proses penanganan gangguan dan variabel lain yang menunjang dalam proses penanganan gangguan menggunakan metode Group Techonology

Dari beberapa sumber literature review maka titik berat dari penelitian ini lebih di fokuskan pada implementasi metode bayes dan group technology dalam aplikasi sistem pendukung keputusan penentuan pemenang tender, sehingga diharapkan hasil dari penelitian adalah dapat mengevaluasi langsung parameter-parameter penentuan pemenang tender serta mengelompokkan kategori pemenang tender berdasarkan jenis paket yang dilelang. 


\section{Sistem Pendukung Keputusan}

SPK dibuat dengan tujuan-tujuan untuk membantu pengambilan keputusan dan memilih berbagai alternatif keputusan yang merupakan hasil pengolahan data dan informasi yang diperoleh dari penggunaan model-model pengambilan keputusan. Adapun ciri-ciri SPK menurut Alters Keen di dalam pustaka Prahasta (2009:106) adalah:

a) SPK ditujukan untuk membantu pengambilan keputusan-keputusan terhadap permasalahan yang kurang terstruktur yang pada umumnya dihadapi oleh para manajer yang berada di tingkat atas.

b) SPK merupakan gabungan antara kumpulan model kualitatif dan kumpulan data.

c) SPK memiliki fasilitas interaktif yang dapat mempermudah hubungan antar-manusia dengan mesin (komputer).

d) SPK bersifat fleksibel dan dapat menyesuaikan diri terhadap perubahanperubahan yang terjadi

\section{Tender Proyek}

Berdasarkan penjelasan Pasal 22 UU No. $5 / 1999$, tender adalah tawaran mengajukan harga untuk memborong suatu pekerjaan, untuk mengadakan barang-barang atau menyediakan jasa. Pengertian tender tersebut mencakup tawaran mengajukan harga untuk:

1. Memborong atau melaksanakan suatu pekerjaan.

2. Mangadakan barang dan jasa.

3. Membeli suatu barang dan jasa.

4. Menjual suatu barang dan jasa.

\section{Kriteria Bayes}

Pada kriteria Bayes akan digunakan nilai harapan (expected value) sebagai dasar penghitungan yang berguna untuk pengambilan keputusan. Istilah nilai harapan (expected value) sangat luas penggunaannya. Di dalam teori pengambilan keputusan nilai harapan payoff merupakan salah satu kriteria dasar pengambilan keputusan. Adapun langkah-langkah yang harus dilakukan adalah sebagai berikut (Widayantoro,2013) :

a. Hitunglah nilai harapan pay-off untuk tiaptiap tindakan yang mungkin.

b. Pilih tindakan yang harapan keuntungan/ perolehannya maksimum.

Untuk menentukan pemenang jasa pemborong, panitia pengadaan jasa pemborongan menggunakan aturan yang di ambil dari Peraturan Menteri Pekerjaan Umum nomor 43/PRT/M/2007 tentang Standar dan Pedoman Pengadaan Jasa Konstruksi yang merupakan Indikator dalam pemilihan penyedia

\section{Group Technology}

Group technology merupakan filosofi dari aktivitas manufaktur. Dalam hal ini komponen yang sejenis diidentifikasi dan dikelompokkan bersama untuk memperoleh keuntungan-keuntungan dalam proses manufaktur maupun desain komponen (Budiarto, 2008) Misalnya ada seribu komponen yang bebeda, mungkin komponen-komponen tersebut dapat dikelompokan dalam 10 atau 15 kelompok besar, yang dapat dianggap sebagai keluarga komponen. Masing-masing keluarga tersebut memiliki karakteristik yang sama atau sejenis dalam hal proses manufakturnya maupun kesamaan desainnya. Jadi bisa dikatakan bahwa ada dua jenis istilah kesamaan komponen, yaitu :

1. Atribut desain ; seperti bentuk dan ukuran

2. Atribut manufakturnya; seperti tahapan pengerjaan komponen. 
Perlu ditegaskan bahwa group technology, pengkodean komponen maupun klasifikasi komponen, adalah sesuatu yang saling berhubungan erat. Dalam menyelesaikan masalah dengan konsep group technology terdapat dua bentuk metode yaitu:

a. Metode Analisis Cluster

b. Metode Klasifikasi dan Kodefikasi

\section{METODE}

\section{Jenis Penelitian}

Jenis penelitian adalah kepustakaan, yang bersumber dari buku-buku referensi seperti textbook dan jurnal-jurnal terkait. Selain itu, untuk melengkapi data-data pendukung penelitian dilakukan juga dilakukan wawancara langsung dengan pihak terkait untuk mengetahui standar prosedur yang ada dalam penentuan pemenang tender.

\section{Teknik Pengumpulan Data}

Pengumpulan data dilakukan melalui:

1. Observasi atau pengamatan

Dilakukan dengan cara mendatangi langsung Unit Layanan Pengadaan dalam kasus ini tempat pengambilan data di Unit Layanan Pengadaan (ULP) Universitas Khairun

2. Wawancara dan Interview

Mewawancarai langsung pihak-pihak yang terkait, dalam hal ini Kepala Unit Layanan Pengadaan (ULP) dan staf terkait serta sumber-sumber lainnya guna mendapatkan gambaran permasalahan yang sebenarnya.

\section{Studi literature}

merupakan sebuah tahapan pencarian dan penelusuran pustaka dari berbagai sumber baik cetak maupun elektronik, seperti textbook dan jurnal-jurnal yang terkait dengan penelitian yang dibuat. Berdasarkan hasil pengumpulan data yang dilakukan kemudian dibuatlah pengelompokan terhadap data yang didapatkan dengan menggunakan metode klasifikasi dan kodefikasi yang ada pada konsep group technology.

Tabel 1 Data Pengelompokan Kategori

\begin{tabular}{|c|c|}
\hline Kode Kriteria & $\begin{array}{c}\text { Kelompok } \\
\text { Kategori }\end{array}$ \\
\hline \multicolumn{2}{|l|}{$01 \mathrm{a}$} \\
\hline \multicolumn{2}{|l|}{$01 b$} \\
\hline \multicolumn{2}{|l|}{$01 c$} \\
\hline \multicolumn{2}{|l|}{ 01d } \\
\hline \multicolumn{2}{|l|}{$01 \mathrm{e}$} \\
\hline $01 f$ & KADM \\
\hline \multicolumn{2}{|l|}{$01 \mathrm{~g}$} \\
\hline \multicolumn{2}{|l|}{$01 \mathrm{~h}$} \\
\hline \multicolumn{2}{|l|}{$01 \mathbf{i}$} \\
\hline \multicolumn{2}{|l|}{$\mathbf{0 1 j}$} \\
\hline \multicolumn{2}{|l|}{$01 k$} \\
\hline $2 \mathbf{a}$ & KKEU \\
\hline \multicolumn{2}{|l|}{$2 \mathrm{~b}$} \\
\hline \multicolumn{2}{|l|}{300} \\
\hline \multicolumn{2}{|l|}{301} \\
\hline 302 & KTEK \\
\hline \multicolumn{2}{|l|}{303} \\
\hline \multicolumn{2}{|l|}{304} \\
\hline \multicolumn{2}{|l|}{305} \\
\hline 306 & \\
\hline
\end{tabular}

\section{Tahapan Perancangan}

Dalam meralisasikan sistem yang dibuat maka dalam penelitian ini metode perancangan sistem yang digunakan salah satunya model air terjun (waterfall) yang disebut model sekuensial linier atau alur hidup perangkat lunak secara sekuensial atau terurut dimulai dari analisis, desain, pengkodean, pengujian, dan pemeliharaan (M.S. Rosa, 2011). Terdapat 5 tahapan yaitu analisis kebutuhan, desain sistem, tahap programming, implementasi dan evaluasi.

Tahap pertama adalah tahap analisis kebutuhan sistem. Kebutuhan dibagi menjadi 2 yaitu kebutuhan fungsional dan kebutuhan nonfungsional. Kebutuhan fungsional meliputi pembagian level pengguna dan klasifikasi kategori sistem misalnya administrasi, keuangan dan teknis 
Kebutuhan non-fungsional meliputi perangkat yang mendukung aplikasi.

Tahap kedua adalah desain sistem. Desain sistem meliputi desain antarmuka dan desain alur kerja program. Yang menjadi fokus pada tahap ini adalah pembuatan desain antarmuka yang mempermudah pengguna dalam mennggunakan sistem.

Tahap ketiga dalam penelitian ini adalah tahap pemrograman. Pada tahap ini dilakukan proses penerjemahan alur kerja sistem kedalam bahasa pemrograman web menggunakan PHP

Tahap keempat pada pengembangan sistem ini adalah tahap implementasi. Tahap implementasi disini berada pada tingkat pengujian sesuai kebutuhan sistem yang ada pada aplikasi sistem pendukung keputusan penentuan pemenang tender

Tahap kelima, merupakan tahapan evaluasi terhadap aplikasi yang dibuat. Pada tahap ini dapat diketahui permasalahan yang ada pada aplikasi, sehingga menjadi acuan untuk di perbaiki kembali.

\section{Alat dan Bahan Penelitian}

Dalam proses perancangan ini, diperlukan alat dan bahan yang dapat mendukung keberhasilan perancangan. Alat dan bahan perancangan yang digunakan adalah :

\section{Alat}

- buah Personal Computer

- buah kamera digital UPS

\section{Bahan}

- $\quad$ Software Xampp 1.8.1
- Microsoft Windows 7 Ultimate

- $\quad$ Macromedia Dreamweaver 8

- Software Database MySQL

- $\quad$ Microsoft Visio 2003

- Hosting/Domain

\section{Teknik Pengujian Sistem}

Model pengujian yang dilakukan dalam penelitian ini adalah black box. Pengujian black box berfokus pada persyaratan fungsional perangkat lunak. Dengan demikian, pengujian black box memungkinkan perekayasa perangkat lunak mendapatkan serangkaian kondisi input yang sepenuhnya menggunakan semua persyaratan fungsional untuk suatu program (Aisa, 2016) Pengujian black box berusaha menemukan kesalahan dalam kategori sebagai berikut:

1).Fungsi-fungsi yang tidak benar atau hilang.

2). Kesalahan interface.

3). Kesalahan dalam struktur data atau akses database eksternal

4). Kesalahan kinerja, dan

5). Inisialisasi dan kesalahan terminasi.

\section{Perancangan Sistem}

Perancangan sistem bertujuan untuk mencari bentuk optimal dari sistem yang akan dibangun dengan mempertimbangkan permasalahan dan kebutuhan sesuai dengan data yang didapatkan. Sebelum melakukan perancangan sistem terlebih dahulu dibuat diagram hierarki terkait data kategori yang akan dikelompokkan menggunakan konsep group technology. 


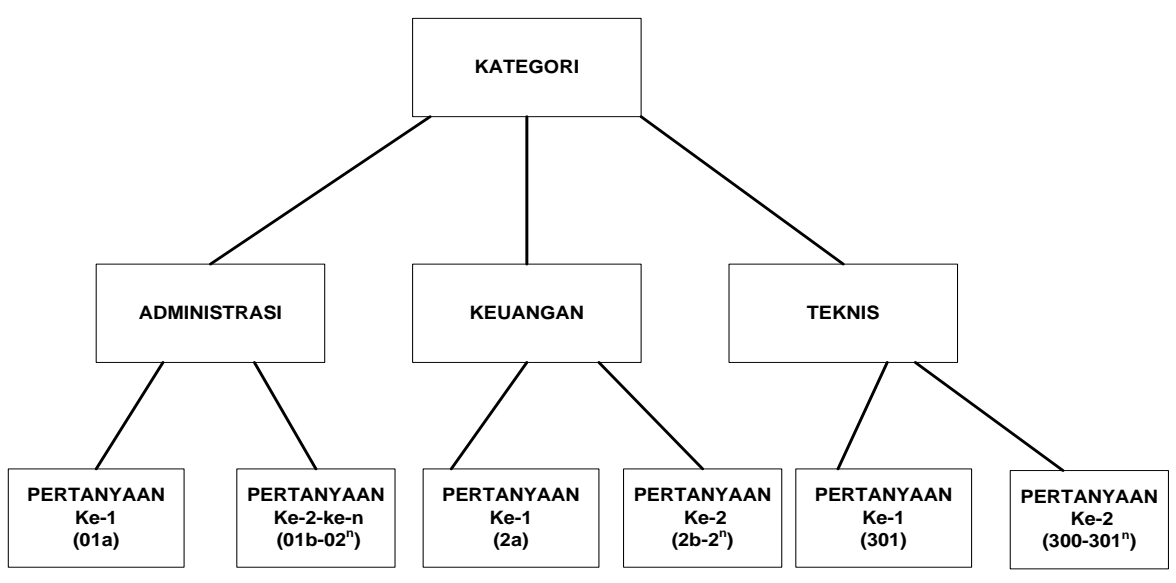

Gambar 1. Diagram Hierarki Pengelompokan Data Kategori

Tahapan selanjutnya merancang diagram konteks terlihat bahwa terdapat 3 (tiga) entitas dalam sistem dari sistem, seperti yang ditunjukan pada Gambar 2, pendukung keputusan pemenang tender

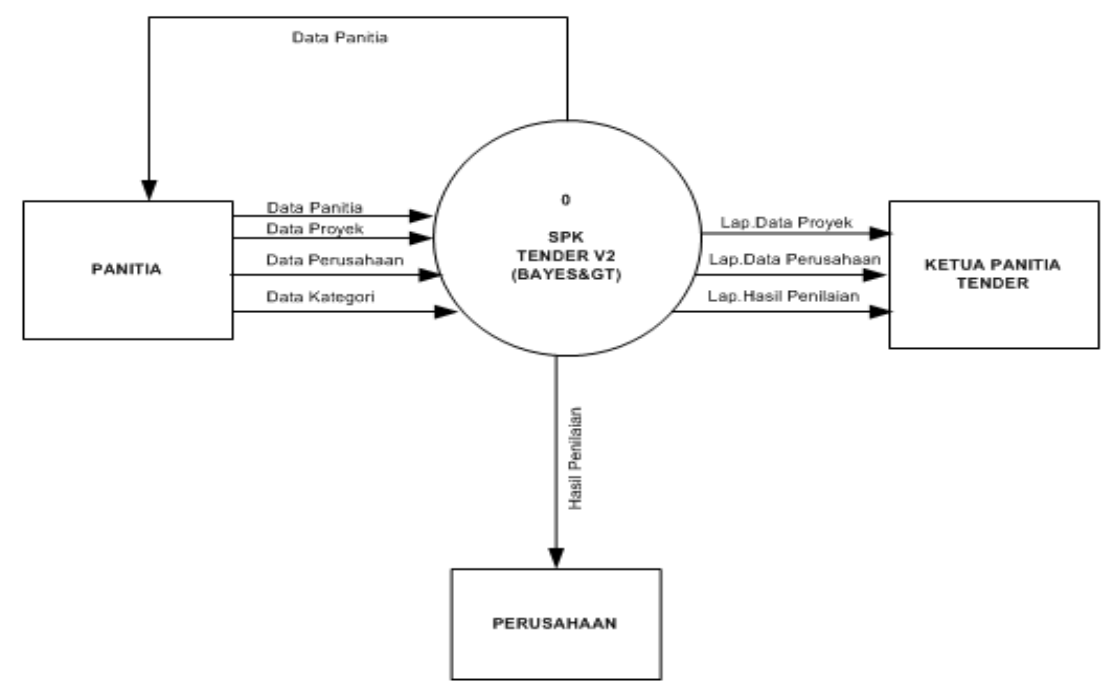

Gambar 2. Diagram Konteks SPK V2 (Bayes \& GT)

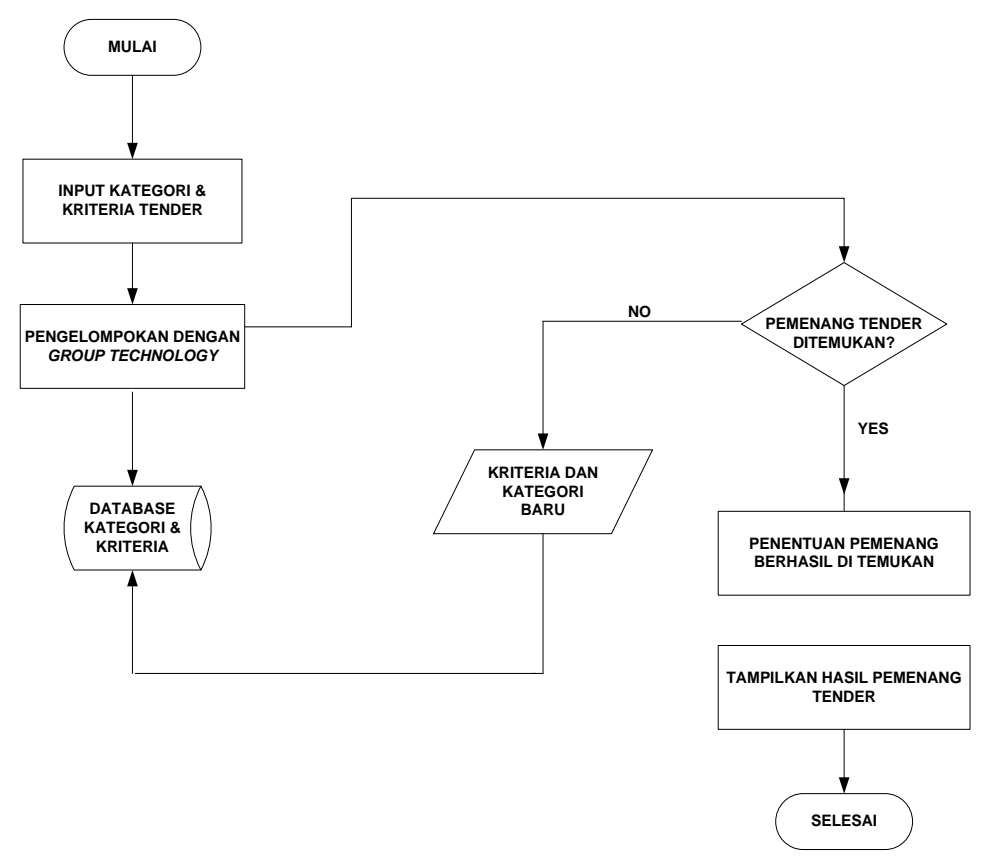

Gambar 3. Flowchart Algoritma Group Technology 


\section{HASIL DAN PEMBAHASAN}

Pada bagian ini, di jelaskan secara detail tampilan aplikasi dan proses yang harus dilakukan dalam menjalankan aplikasi ini sampai selesai. Berikut ini tampilan aplikasinya :

\section{a. Form Menu Utama}

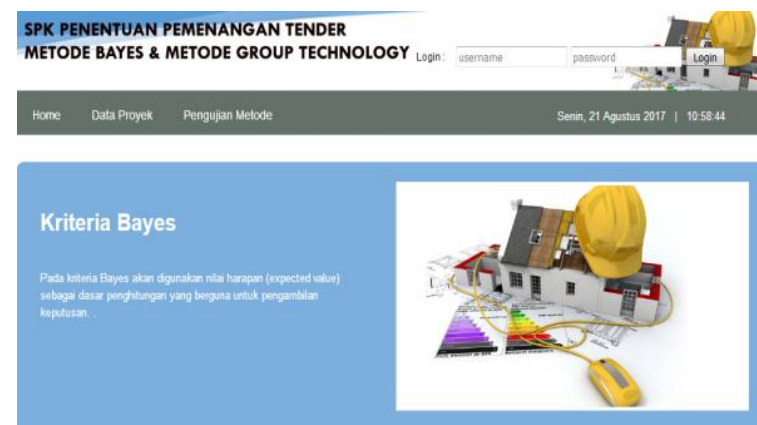

Gambar 4 Form Menu Utama

Form menu utama merupakan tampilan awal aplikasi Sistem Pendukung Keputusan Penentuan Pemenang Tender. Halaman menu utama memiliki 3 menu utama yaitu, Menu Home, Menu Data Proyek
(Data-Data Perusahaan), serta menu pengujian metode. Melalui menu pengujian metode dapat dilakukan pengujian terhadap dua jenis metode yang digunakan yaitu: metode bayes dan metode group technology.

\section{b. Form Login}

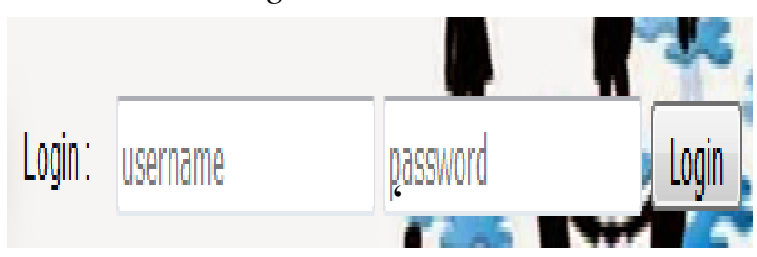

Gambar 5 Form Login

Halaman login merupakan halaman yang digunakan oleh user/admin untuk dapat login ke laman dashboard Administrator dengan memasukkan username dan password

c. Form Pengujian Metode

Form pengujian metode digunakan untuk menguji metode yang digunakan. Dalam hal ini metode bayes dan metode group technology.

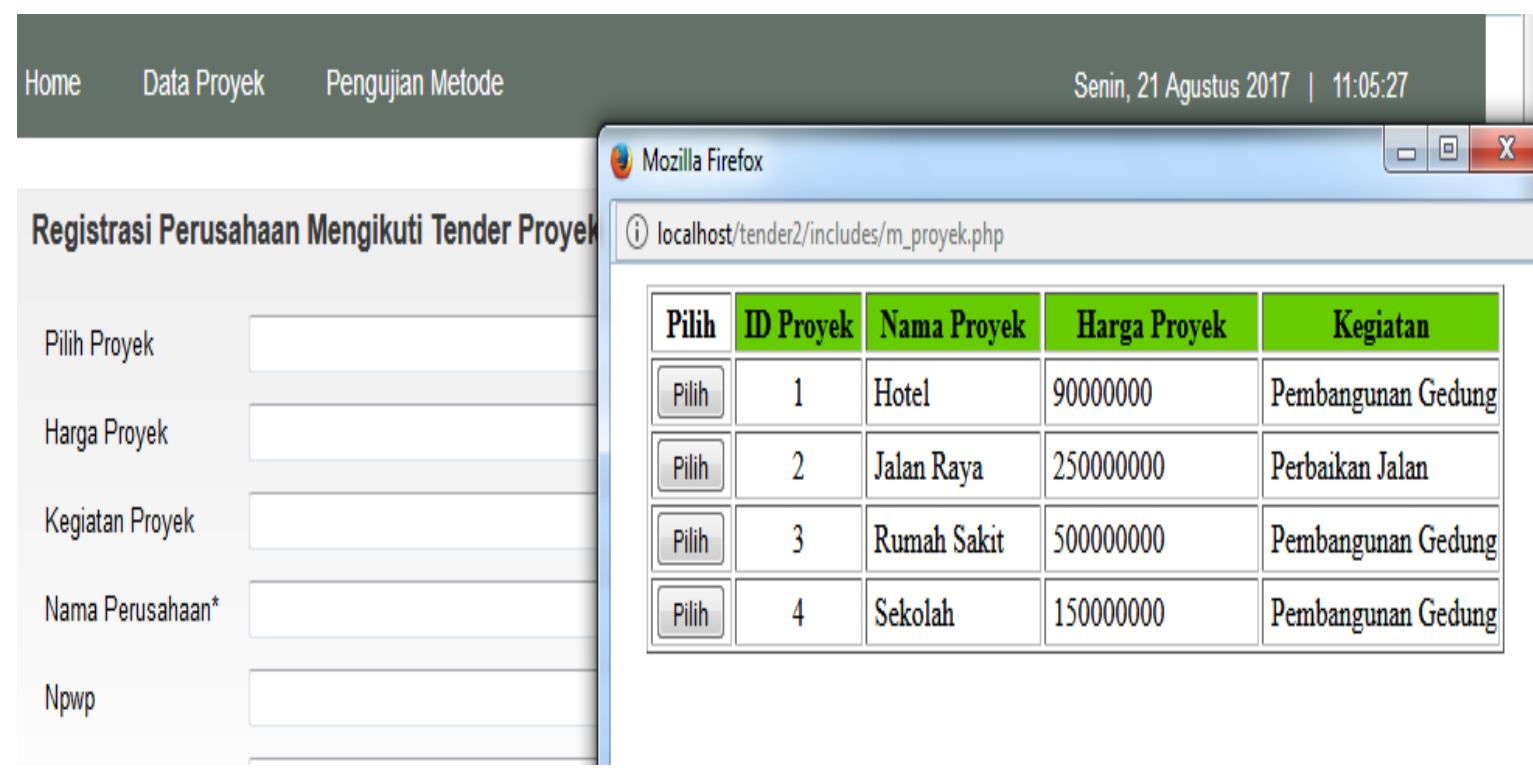

Gambar 6 . Form Pengujian Metode bayes

Pada Form Pengujian metode bayes ketika pengguna meng-klik tombol pilih proyek maka secara otomatis akan diarahkan pada sebuah form daftar proyek yang ditenderkan beserta harga yang ditawarkan. Setelah memilih jenis proyek maka akan dilanjutkan untuk mengisi kolom-kolom yang ada. Kemudian dilanjutkan dengan mengklik tombol proses maka akan diperlihatkan pertanyaan terkait administrasi, keuangan dan teknis. Dalam tahap ini berdasarkan data yang dimasukkan maka akan muncul skor hasil perhitungan masing-masing kategori yang akan menentukan hasil akhir dari proses penentuan pemenang tender. Gambar 7 memperlihatkan 
hasil akhir pengujian dengan metode bayes. Selanjutnya dapat dilihat pada Gambar 8 untuk hasil pengujian dengan metode Group technology

Perhitungan Skor Masing-masing Kategori dari Perusahaan : PT Siso

\begin{tabular}{|l|l|l|l|l|}
\hline No & \multicolumn{1}{|c|}{ Nama Kategori } & \multicolumn{1}{|c|}{ Skor Hasil Pendataan } & Setengah Dari Bobot Kategori & \multicolumn{1}{|c|}{ Probabilitas } \\
\hline 1 & Administrasi & 14 & 7 & 0.424 \\
\hline 2 & Keuangan & 2 & 1 & 0.061 \\
\hline 3 & Teknis & 17 & 8.5 & 0.515 \\
\hline
\end{tabular}

Hasil Perhitungan Akhir

\begin{tabular}{|l|l|l|l|l|}
\hline & \multicolumn{1}{|c|}{ Administrasi } & \multicolumn{1}{c|}{ Keuangan } & \multicolumn{1}{c|}{ Teknis } & \multicolumn{1}{c|}{ Total } \\
\hline Hasil Pendataan & 0.0571428571429 & 0.061 & 0.0606060606061 & 0.121606060606 \\
\hline Nilai Ambang & 2.968 & 0.061 & 4.38 & 4.4385 \\
\hline Kesimpulan & Lulus & Gagal & Lulus & Lulus \\
\hline
\end{tabular}

Gambar 7. Form Pengujian Metode bayes

PROSES DAN HASIL UJI METODE GROUP TECHNOLOGY

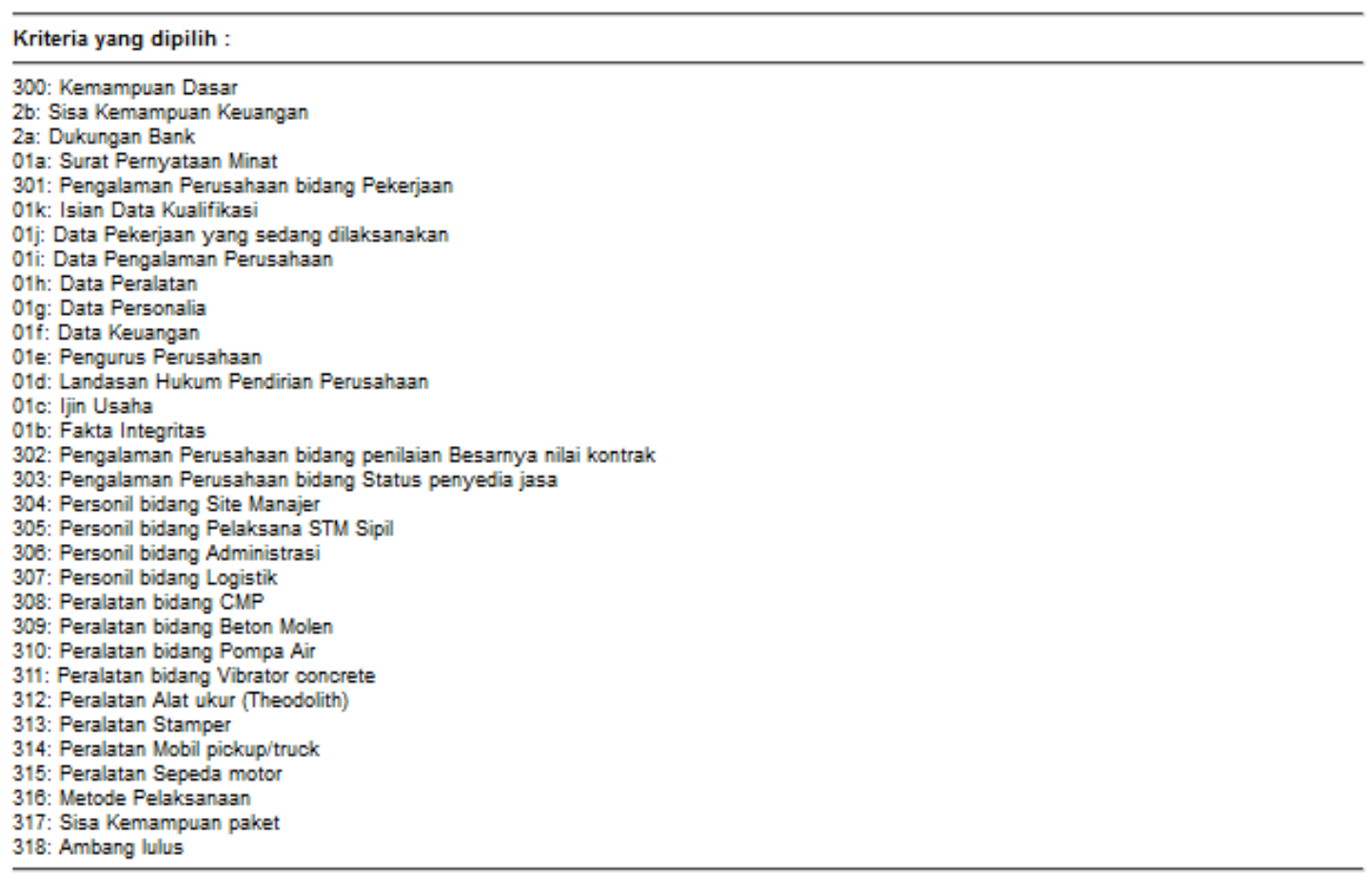

Hasil yang didapat adalah prosentase tingkat kebenaran sebesar 100\%. Sedangkan prosentase hasil analisis system ke dua adalah Prosentase tingkat kebenaran mendapat $0.1734375 \%$

Gambar 8. Form Pengujian Metode bayes

\section{PENUTUP}

Berdasarkan hasil pengujian yang dilakukan didapatkan bahwa telah dikembangkan aplikasi sistem pendukung keputusan berbasis web menggunakan metode bayes dan Group technology untuk digunakan dalam penentuan pemenang tender. 


\section{UCAPAN TERIMA KASIH}

Penulis mengucapkan terima kasih kepada pihak yang telah memberikan bantuan baik dari sisi penyelesaikan serta implementasi dari sistem ini. Sehingga penelitian ini dapat di sajikan dalam bentuk jurnal.

\section{DAFTAR PUSTAKA}

Aisa, S. (2016). Implementasi Private Cloud Menggunakan Raspberry PI Untuk Pengaksesan Data Pribadi. Jurnal Penelitian Pos Dan Informatika, 6(2 Desember), 137152.

https://doi.org/http://dx.doi.org/10.17933/jpp i.2016.060202

Budi, A. (2014). Menggunakan Metode Group Technology Untuk Pelayanan teknis PT PLN Rayon Ngunut. EECCIS, 8(2 Desember).

Budiarto. (2008). Peningkatan Efisiensi Proses Melalui Perancangan Jig dan Fixture Pada Implementasi Group Technology. Institut Teknologi Sepuluh Nopember, Surabaya.

Jamil M. (2010). Pengembangan Sistem Informasi Kepariwisataan Berbasis Web dengan Konsep Group Technology Dalam Rangka Inventarisasi Aset Pariwisata Di Propinsi Maluku Utara. Jurnal Teknologi Informasi Malang, 1(2).

M. S. Rosa. (2011). Modul Pembelajaran Rekayasa Perangkat Lunak (Terstruktur dan Berorientasi Obyek). Modula, 53(11).
Mirwan, S. (2011). Sistem Penunjang Keputusan pemenang tender menggunakan metode Anlytical Hierarchy Process (AHP) Pada Dinas Pekerjaan Umum Kabupaten Aceh Utara. Universitas Serambi Mekah, Banda Aceh.

Nugraha, Fajar, Suararso Bayu, N. B. (2012). Sistem Pendukung Keputusan Pemilihan pemenang penggadaan aset menggunakan metode Simple Additive Weigthing. Sistem Informasi Bisnis.

Prahasta, E. (2009). Sistem Pendukung Keputusan (SPK)" dalam Sistem Informasi Geografis: Konsep-Konsep Dasar (Perspektif Geodesi \& Geomatika) (Pertama). Bandung: Informatika Bandung.

Siska, K. D. (2014). Sistem Pendukung Keputusan Seleksi Penyedian Pengadaan Jasa Konstruksi dengan metode evaluasi penawaran Merit Point Sistem di Politeknik Negeri Bandung. Jurnal Informasi, $6(2$ November).

Surjawan Jahja, D, A. G. (2012). Sistem Lelang Tenderdan Dealing online Berbasis web (Studi Kasus PT X). Jurnal Sistem Informasi, 7(1 Maret).

Triat, W. (2013). Sistem Pendukung keputusan pemenang lelang proyek pemerintah menggunakan metode bayes. Universitas Dian Nuswantoro, Semarang. 